\title{
The contribution of instructional leadership and followership styles to the teachers' performance in elementary school
}

\author{
Eka Wira Putra ${ }^{1}$, Rusdinal ${ }^{2}$, Yahya ${ }^{3}$ \\ ${ }^{123}$ Universitas Negeri Padang, Padang - Indonesia, (ekawiraputra26@gmail.com)
}

\begin{abstract}
The objectives of the research are to find out and explain, the contribution of instructional leadership to the teachers' performance, contribution followership style to the teachers' performance, contribution of instructional leadership and followership style to teachers' performance in elementary school in Batahan district. This research using quantitative method with correlational approaches. The population is all the civil servant teachers in elementary school in Batahan district 110 teachers. Sample are 59 teachers by stratified proportional random sampling technique. The instrument use likert scale and the reliability 0,944 . Data analysis technique is processed by using correlation and regression with help of SPSS version 20 program. Based on the analysis results can be concluded as follows: instructional leadership contributes significantly to the teachers' performance, followership style contributes significantly to the teachers' performance, instructional leadership and followership style contribute significantly to teachers' performance in elementary school in Batahan district Mandailing Natal regency, North Sumatera.
\end{abstract}

Keywords: instructional leadership, followership styles, performance

\section{Introduction}

The development of science and technology has brought about changes in almost every aspect of human life where as the problem can only be solved except by the effort of mastery and improvement of science and technology. In addition to the benefits to human life on the one hand these changes also bring humans into the era of global competition. Improving the quality of human resources is a fact that must be done in a planned, directed, intensive, effective, and efficient in the development process, if you do not want this nation lost competitiveness in the era of globalization.

Regarding the quality of human resources, education plays a very important role in the process of improving the quality of human resources, as Rivai found, 2010 that the improvement of the quality of education is a process integrated with the improvement of the quality of human resources itself. Teachers are the backbone of educational activities, especially those related to teaching and learning activities.Without the role of teachers, the teaching and learning process will be disrupted and even failed. Therefore, in educational management the role of teachers in the success of education is always improved, teacher work performance or performance should always be improved given the challenge of education to produce quality human resources that can compete in the global era. 
Teachers are one of the educational staff who have a role as one of the determinants of the success of educational goals, because teachers are directly in contact with learners, to provide guidance that will produce the expected graduation. Teachers are human resources who become planners, actors and determinants of achieving organizational goals.

Teacher performance is a ability of teachers in carrying out activities as a whole to the work that is the responsibility of someone or more, performance is also meaningful as work that describes the quality of one's work within an organization. School as a form of organization in education is seen as a system .

According to Barnawi and Arifin (2012: 14) the performance of teachers can be interpreted as the success rate of teachers in carrying out educational tasks in accordance with the responsibilities and authority based on performance standards established during a certain period in the framework of achieving educational goals.

In the learning activities undertaken not all teachers have the ideal performance of the teacher profession. Teachers who have the performance are teachers who have learning skills, insightful scientific knowledge, extensive social insight, and a positive attitude to his work. Teacher performance will be optimal if it is integrated with the existing components in the school whether principals, teachers, education personnel and learners and create high discipline in school.

According Wibowo (2011: 2) performance is doing the job achieved from the job, performance is about what is done and how to do it. Not much different from Rivai (2005) suggests that performance is the result or success rate of a person as a whole over a certain period of time in performing tasks compared with various possibilities, such as predefined work standards, predetermined targets or targets or criteria agreed together.

According Timpe (2005) there are several factors in the performance consisting of internal factors and external factors. Furthermore, the factors of performance consist of internal factors and external factors, internal factors (dispositional) is a factor associated with the characteristics of someone. Whereas external factors are factors that affect the performance of someone who comes from the environment. Like behavior, attitude, and actions of co-workers, subordinates or leaders, work facilities and organizational climate. (In Mangkunegara, 2006: 15).

Leadership in an organization is often the greatest concern that is most often the case especially in a school organization Leaders themselves are often sought after by school organizations to maintain the quality of education with the expectation of leaders able to contribute best to the company. The problem that is often overlooked by the school organization is what is the use of the leader figure but the leader himself has no followers which means no one executes the direction of a leader. Followers themselves are actually more defined not as subordinates, but individuals with a free will to decide who they are with and to leaders they trust to work together to succeed. Followers who strongly contribute to the leadership is definitely needed effort with the provision of motivation and build closer relationships between individuals. Thus it is clear that the follower is the most important part of the leadership element, not just the leader (Susan, 2012). Instructional Leadership is a leadership that focuses and emphasizes learning that includes curriculum, teaching-learning process, assessment, assessment and development of teachers, excellent service in learning, and development of learning communities in schools. (Kemdiknas, 2011: 12).

Daft (2005) develops the concept of influence and achievement of this goal in the definition of leadership: " Leadership is an influence relationship between leaders and followers who intend real changes and outcomes that reflect their shared purposes (h.5)". In this context added is the existence of mutual influence between the leader and the led. That leader will also be influenced by the reaction 
of the person he leads, vice versa. Leadership also implies the intention of the leading and the led to make a meaningful change, which is not only dictated from the leader, but is a reflection of the wishes of both leaders and those led. This definition also implies that leadership takes place between individuals, that is, leaders are individuals who have followers and can be examples for other individuals to move.

Leadership of principal's learning has an effect on the school effectively, the results of research David and Thomas, et.al. (Muliati: 2012) suggests that an effective school requires strong learning leadership from the principal. Empirical facts in Sumarno's research (2015) proves that instructional leadership of primary school principals in Gegesik sub-district of Cirebon regency gives 53,9\% influence to effective school.

Kusnadi (2005: 353) argues that leadership not only means leaders and influences people, but also leaders to change and source of aspirations and motivation of subordinates. Winardi (2000: 47) means that leadership is a capability inherent in a person who leads, which depends on the various, internal and external factors, including people; work from an organizational position; and arise in a specific situation. So that leadership arises, if the three factors are mutually affect each other that is the situation and position there, the people also exist.

The style to followers that the organization desperately needs, is a follower whose job it is to support, not to undermine or overthrow its leadership, because it has made a great contribution to a good followers organization always speaking honestly and bravely discussing always with superiors when their bosses make mistakes. It is not uncommon to think about the following about the magnitude of the contributions that followers give to their superiors to make followers confused about the decisions of followers who have chosen to contribute greatly to their superiors. Followers who have chosen to be loyal and willing to contribute greatly to their superiors gain trust that their own beliefs are something that is actually quite rare to obtain and must also be possessed by the relationship between followers and leaders (Barry, 2011).

Participation is not a passive role. Conversely, the most valuable followers are a skilled, independent employee, an active participant in setting the direction of the group, investing time and energy in group work, critical thinking, and support for new ideas (Grossman \& Valiga, 2000) .

According to Kelley (1992) the main characteristic of the type of Allienated Followers (followers estranged) is critical thinking high while the degree of participation in work is low. He is passive in acting but very critical of organizations and leaders. Followers of this type are followers who add to the injury to the organization, a constant irit that shows a negative aspect (never indicates a positive aspect) of the organizational goals, policies and procedures.

The objectives of the research are to find out and explain: 1) Contribution of learning leadership to teacher performance in Batahan Sub-district, Mandailing Natal District, North Sumatera.2)Contribution style style to the techers' performance in Batahan district, Mandailing Natal regency, North Sumatra .3) Contribution of instructional leadership and followership styles to the teachers' performance in Batahan District Mandailing Natal regency of North Sumatra.

\section{Method}

This study uses quantitative methods with correlational research to see the strength of the relationship between learning leadership variables and alienated follower with the performance of elementary school teachers Batahan District Mandailing Natal District. The population of this research is all teachers of SD District of Batahan PNS in Regency Mandailing Natal which amounts to 110 people. The sample of this study was taken using statistical proportional random sampling 
technique. Data collection is done by meeting the subject of research directly. Data analysis technique of this research will be processed by using correlation and regression techniques with the help of SPSS version 20 program.

\section{Results and Discussion}

The first hypothesis tested in this study is the instructional leadership contribute to teacher performance, to test this hypothesis correlation analysis can be seen in Table 1 .

Table 1. Summary of Results Analysis Correlation Instructional leadership $\left(X_{1}\right)$ on teacher performance $(\mathrm{Y})$

\begin{tabular}{lllll}
\hline Correlation & Correlation Coefficient (r) & $\begin{array}{l}\text { Coefficient } \\
\text { Determination }\end{array}$ & of & P \\
\hline (ryl) & 0.434 & 0.188 & 0,000 & \\
\hline
\end{tabular}

The result of calculation in Table 1 shows that the correlation coefficient between instructional leadership and performance of teacher is equal to $=0,434$ with $p<\alpha(0,000)$. Based on the results of this calculation can be explained that the instructional leadership contribute to teacher performance, and form a positive relationship with the coefficient of determination $=0.188$.

Descriptive analysis results illustrated that the indicator of the instructional leadership aspects included in the category of sufficient is to analyze the results of student achievement, this includes into the category enough, from the results of the questioner spread from the information that the principal lack of give presiasi to teachers for the success of students in learning and principals are less motivating teachers to achieve student graduation as expected.

Sometimes not all teacher difficulties can be understood by the principal, whereas, by knowing the difficulties faced by teachers in learning, the principal can find solutions handling or alternative solutions appropriate to overcome the difficulties faced by teachers in learning, especially to overcome the difficulties of teachers, then the principal can vary the use of methods or approach coaching according to the existing problems so that can evoke analytical skills, and critical thinking skills of teachers.

Factors considered to influence teacher performance include principal leadership (Kelley, et al., 2005), work motivation (Ofoegbu, 2006), and infrastructure (Buckley, et al., 2005). These three factors affect teacher discipline which in turn affect the performance of teachers in some aspects.

Principal leadership factors can affect teacher performance because principal leadership is an important factor that can determine the working climate in schools. The influence of the principal's leadership on teacher discipline according to Harris, et al., (2003: 70) which explains that the principal's leadership role is " giving the school direction, having an overview, setting standards, and making tough decisions." conducive to improving teacher work discipline which in turn will improve teacher performance. Webb, et al., (2006); Kelley, Thornton and Daugherty (2005) and Ovando and Ramirez (2007) concluded that the principal's leadership was able to influence teacher performance . 
The second hypothesis examined in this study is followership styles contribute to teacher performance, to test this hypothesis is done correlation analysis can be seen in Table 2 .

Table 2. Summary of Results of Correlation Analysis followership style $\left(X_{2)}\right.$ to Teachers' Performance (Y)

\begin{tabular}{lllll} 
Correlation & Correlation Coefficient (r) & $\begin{array}{l}\text { Coefficient } \\
\text { Determination }\end{array}$ & of & P \\
\hline (ryl) & 0.349 & 0.121 & 0,000 &
\end{tabular}

The result of calculation in Table 2 shows that the coefficient of correlation between the following styles to teacher performance is $=0.349$ with $\mathrm{p}<\alpha(0,000)$. Based on the results of this calculation can be explained that the followership styles highly correlated to the performance of teachers, and the form of positive relationship with the coefficient of determination $12.1 \%$ on teacher performance.

The result of descriptive analysis of the lowest indicator is in the most low aspect of the passive follower. In line with research (2005) In passive followers only 5-10\% of all followers are included in this style (Hughes et al., 1999). quotes Meindl and Ehrlich, say that organizational successes and failures are sometimes unfairly attributed to leaders, although followers are the real reason for the success and failure of an organization.

In the active and passive dimension, a good follower is an individual who takes the initiative, has a sense of belonging to a group or team of work, participates actively, begins everything from self, and hardworking. Conversely, bad followers are lazy, passive, constantly in need of encouragement, requiring constant supervision, and avoiding responsibility.

Participation is a process whereby followers support leaders' views and consciously work to achieve the goals shared with leaders or organizations. While followers are the ones who recognize that the leader is the main source that guides their work and they actively play a role in supporting the leadership's view in order to achieve the goal. Based on these definitions it is clear that followers perform an active role and not merely passive, conformist, and weak.

Another aspect that is included in the category is enough that the indicators design curriculum assessment and learning, this is still not given the guidance by the principal to the teacher in concept so that there are still many teachers who do not understand in assessing the achievement of students in particular learning.

Meilinger (2007), has also explained the rules of discipline in which all existing rules must be based on the willingness of superiors and subordinates to work together. The results of cooperation and reciprocity between good employees, making the boss's wishes on employees can be delivered to employees who embodied in the company's activities. Principals who want teachers to make targets real have been realized by teachers in schools where teachers complete them at a faster pace to become more liked and trustworthy leaders and, if necessary, exceed targets .

The third hypothesis tested in this study is that leadership leadership and participant style contribute to teacher performance to test this hypothesis by double correlation analysis. The results can be seen in Table 3. 
Table 3. Summary of Instructional Leadership Correlation Analysis $\left(X_{1}\right)$ and Followership Style $\left(\mathrm{X}_{2}\right)$ to the teachers' performance $(\mathrm{Y})$

\begin{tabular}{llcc}
\hline Korela si & Correlation Coefficient (R) & $\begin{array}{c}\text { Coefficient of } \\
\text { Determination }\left(\mathbf{R}^{2}\right)\end{array}$ & $P$ \\
\hline (ryl2) & 0.510 & 0.260 & 0,000 \\
\hline
\end{tabular}

Results of the calculations in Table 3 shows that multiple correlation coefficient learning leadership and followership style together with teacher performance variables (R 2 y 12) is approximately 0.510 with $\varrho=0.000<\alpha=0.05$ and a coefficient of determination ( 2 Y 12 ) of 0.260 . Thus it can be stated that instructional leadership and followership style of sharing together contribute significantly to teacher performance.

Leadership in an organization is often the greatest concern that is most often the case especially in a school organization. The figure of leader itself is more often dicara by school students.Followers are needed by organizations and leaders, are followers who are able to contribute positively as well as leaders. Contributing followers are more active followers to express their own opinions and do not rule out having a high initiative in action. In fact, active followers are very rarely found by companies. Passive followers mostly arise when there is a power from a boss that makes followers feel depressed, so followers often prefer safe paths and avoid differences of opinion with their superiors, that is to listen to the boss's orders and to run according to the command leadership rather than an active and critical-thinking role to his superiors who often misunderstand and raise some conflicts. True followers need to be encouraged more to participate in greater ways to exert more influence for the company and do not rule out the possibility of encouraging a change in the organization. These active followers dare to express their opinions and dare to declare the truth if his boss has done wrong and has integrity. It is these followers who really need to be in a company other than a leader who can provide direction.

A leader is someone who has followers who have chosen to follow his lead: a responsible person of a group may not be a leader, or may be a leader only to some people under his authority (Barry, 2011).

Followers who are needed by the organization, are followers whose job is to support, not to undermine or to overthrow its leadership because it has successfully contributed greatly to the organization. A good follower always talks honestly and dares to discuss always with his boss when his boss makes mistakes. It is not uncommon to think about the following about the magnitude of the contributions that followers give to their superiors to make followers confused about the decisions of followers who have chosen to contribute greatly to their superiors. Followers who have chosen to be loyal and willing to contribute greatly to their bosses gain trust where self-belief is something that is actually quite rare to obtain and must also be possessed by the relationship between followers and dreamers.

According to Timpe (2005) there are several factors 11). in performance consisting of internal factors and external factors. Furthermore, the factors of performance consist of internal factors and external factors, internal factors (dispositional) is a factor associated with the characteristics of someone. Whereas external factors are factors that affect the performance of someone who comes from the environment. Like behavior, attitude, and actions of co-workers, subordinates or leaders, work facilities and organizational climate. (In Mangkunegara, 2006: 15).

Followers have as important a role as a leader. The role of followers has now shifted, no longer just to follow the direction of the leader, but to have an active role as a collaborator, assessor, influencer, and constructor for leaders . 
Limitations This study has been carefully conducted on the basis of appropriate methods and procedures with type this research. However the perfection of results is appropriate for this type of research. But the perfection of results is not easy to manifest. This is the best result right now, despite the limitations and weaknesses encountered during the research process.

This research is inseparable from the limitations and weaknesses that can not be avoided even though the instrument has been designed and has been tested for its validity and reliability. But the seriousness and truth of the response given by the respondents is difficult to be controlled by the researcher. Especially aspect of honesty and sincerity in filling instrument. Because it could be the response given to the proposed questionnaire items are not in accordance with the actual situation, due to the anxiety of respondents that the filling of research instruments will affect their condition if the answer in accordance with the actual situation. Although from the outset researchers have informed that the data provided will only be used for this study and will not have any effect on their condition. Therefore researchers need to get the assumption that the response is given to the items of the instrument statement already could give donations picture which are actually in accordance with what is to be expressed through research instruments.

\section{Conclusions}

Based on the results of analysis, it can be concluded as follows: 1) Instructional leadership contribute $18.8 \%$ to the teachers' performance in elementary school in Batahan district Mandailing Natal regency North Sumatra. 2) Followership styles contribute to the performance of teachers SDN Kecamatan Batahan Mandailing Natal District of North Sumatra with a magnitude of 0.349 with a contribution of $12.1 \%$.3) Contribution of Leadership Learning and Style of Participation to Teacher Performance SDN Batahan Sub-district Mandailing Natal District of North Sumatera together contributes to teacher performance of 0.510 This explains that to improve teachers' good and idealperformance should be improved teacher performance through leadership exemplary .

\section{Acknowledgments}

Thanks to my first advisor who helped me in write this research, and also to my second advisor. And all my friends help me to finish this research.

\section{References}

Anwar Prabu Mangkunegara. (2004). Manajemen Sumber Daya Manusia. Perusahaan cetakan pertama, penerbit. Remaja Rosdakarya.

Anwar, Q dan Sagala, S. (2004). Profesi Jabatan Kependidikan dan Guru Sebagai Upaya Menjamin Kualitas Pembelajaran. Jakarta. Uhamka Press.

Arikunto, S. (2006).Prosedur Penelitian: Suatu pendekatan Praktik. Jakarta: Rineka Cipta.

Barnawi and Arifin, Muhammad. (2012). Etika \& Profesi Kependidikan. Yogyakarta: Ar-Ruz Media.

Barnawi and Arifin, Muhammad. (2012). Kinerja Guru Profesional. Jogjakarta: Ar-Ruz Media.

Bennis, WG Followership-from an invented life. "Reflections on leadership and change":

//www.cio.com/research/executive/edit/chapter11.html? Action = print Retrieved April 7, 2017

Buchari, Zainun. (2000). Manajemen and Motivasi . Jakarta: Balai Literature.

Budiarto, Johanes. (2005). Followership : Sisi Lain Kepemimpinan yang terlupakan. Journal.

Danim, Sudarman. (2004). LMotivasi kepemimpinan dan Efektifitas Kelompok. Penerbit Rineka Cipta.

Daft, Richard L. (2006). Manajemen, Edisi Keenam Jakarta: Salemba Empat.

Fred C. Lunenburg Allan C. Ornstein. (2008). Educatioin Administration. Thomson.USA.

Gibson, Ivansevich, and Donelly. (1995). Organisasi: Perilakur, Struktur, Proses, Jilid 2, Binarupa Aksara, Jakarta. 
Hughes, RL, Ginnett, RC, \& Curphy, GJ. (1999). Leadership: Enhancing the lessons of experience (3rd ed.) ", Irwin McGraw-Hill: Boston

Johnson, Barry. (2011) . Good Followership . United Kingdom: Training Journal. Kelley, Robert. (1992). The Power Of Followership. New York: Doubleday Currency McClelland, DC . (1987). Human motivation . Glenview, IL: Scott, Foresman. 